\title{
Life Cycle Assessment of a Small Hydropower Plant in the Brazilian Amazon
}

\author{
Marla T. B. Geller ${ }^{* 1}$, Anderson A. d. M. Meneses ${ }^{2}$ \\ ${ }^{1}$ Postgraduate Program in Society, Nature and Development, Federal University of Western Pará, \\ Av. Mal. Rondon, Caranazal, Santarém, Brazil \\ e-mail: marla.geller@gmail.com \\ ${ }^{2}$ Institute of Geosciences and Engineering, Federal University of Western Pará, Av. Mal. Rondon, \\ Caranazal, Santarém, Brazil \\ Postgraduate Program in Society, Nature and Development, Federal University of Western Pará, \\ Av. Mal. Rondon, Caranazal, Santarém, Brazil \\ e-mail: anderson.meneses@pq.cnpq.br
}

Cite as: Geller, M. T. B., Meneses, A. A. d. M., Life Cycle Assessment of a Small Hydropower Plant in the Brazilian Amazon, J. sustain. dev. energy water environ. syst., 4(4), pp 379-391, 2016, DOI: http://dx.doi.org/10.13044/j.sdewes.2016.04.0029

\begin{abstract}
Brazil as well as the rest of the world, faces a major challenge related to the electricity sector, to meet the growing demand with energy production from renewable sources. Many hydroelectric plants are being implemented, especially in the northern region of Brazil, but its environmental impacts are yet unknown. Energy produced by hydropower plants has been considered totally renewable and clean, but more recent studies describe analysis pointing to the existence of emissions by hydroelectric plants, especially if a lifecycle approach is considered. Thus, the objective of this study is the investigation of environmental impacts of the construction, operation and decommissioning of a hydroelectric power station based on life cycle assessment. The main focus is the Curuá-Una hydropower plant that is located in the Amazon forest in northern Brazil, in Santarém municipality (Pará state).
\end{abstract}

\section{KEYWORDS}

Curuá-Una hydropower plant, Amazon rainforest, Life cycle assessment, Environmental impact.

\section{INTRODUCTION}

A major challenge with regard to the energy sector in the coming years is to produce clean energy at low cost and minimal emissions, with sufficient capacity to meet the growth in demand. The Energy Research Office (Empresa de Pequisa Energética - EPE) studies record the growth forecast of the world economy of $3.7 \%$ per year for the next 10 years, which consequently leads to an increase in electricity consumption to meet the different sectors such as industry, services, households, etc. [1].

Brazil's electrical demand in 2014 was 463.1 TWh and the Brazilian Energy Planning has considered scenarios with increased electricity consumption of $3.9 \%$ per year until 2024 [2]. In addition, research from the International Energy Agency (IEA) acknowledges the electricity sector as responsible for $40 \%$ of Greenhouse Gas (GHG) emissions, being considered an important factor of environmental impact and consequently of climate change [3].

\footnotetext{
* Corresponding author
} 
Discussions on the subject already in the 70's (World Climate Conference), pointed the need for action on climate change. In 1997, the Kyoto protocol established the commitment of many countries to reduce GHG emissions. Thus, the search for possibilities of replacing products and processes that have significant amounts of GHG emissions by those more sustainable has increased, including energy production from renewable sources.

Hydropower Plants (HPP) generate most of the electricity produced in Brazil (65\%) and there are more projects for implementation in order to increase production. The hydroelectric potential of the northern region alone is estimated at 100,370 MW $(40.6 \%$ of all Brazil), examples of which are the Belo Monte HPP on the Xingu River (to enter into operation in 2016, with 4,500 MW) and other planned plants [4]. Thus, the northern region is configured as the major power generator in the country, with potential for development given its strategic position. However, such potential of the region in the electricity sector should be further investigated because, although several studies point out that the hydropower is considered a renewable source with low environmental impact [3], some researches show that there exists environmental impact factors linked to these plants, especially in dams located in rainforest areas [5, 6].

Knowing the environmental impacts of different product systems is an essential requirement for decision-making that can be achieved with Life Cycle Assessment (LCA). LCA is an environmental management tool defined as "a process to evaluate the environmental burdens associated with a product, process, or activity by identifying and quantifying energy and materials used and wastes released to the environment, and to identify opportunities to effect environmental improvements" [7]. LCA enables identification of the most significant impacts and the stages to be observed for improvement, avoiding the damage to be spread from one stage to another, an environmental problem to another or from one region to another within a systematic and holistic approach [8]. According to ISO 14040, LCA shall include four steps: definition of goal and scope, inventory analysis, impact assessment and interpretation of results [9].

Currently, the LCA is being used for decision making in choosing the best option in many contexts as chemical engineering [10], use of disposable packaging [11], transporting products [12], and frequently in energy production. For example, Yue et al. [13] used LCA to study the sustainable design of potential hydrocarbon biofuel supply chain network. Guinee et al. [14] review the history of the LCA and discuss current and future developments; and Finkbeiner [15] used LCA as basis for environmental declarations and carbon footprint of products. Queiroz et al. [16] used LCA to analyze the energy balance of biodiesel production from palm oil in the Amazon. Dones et al. [17] implemented LCA to cover all main energy chains associated with installed electricity and heating technologies, with focus on the Swiss and Western Europe. Matuszewska [18] used LCA to identify the optimal configuration for geothermal systems. Garcia-Valverde et al. [19], Desideri et al. [20] and Laleman et al. [21] applied LCA to estimate the environmental impact of photovoltaic systems. Brizmohun et al. [22] implemented LCA to analyze the electricity generation in Mauritius. Many authors have analyzed HPP's lifecycles because of the importance of hydropower in the world scenario [23-25].

LCA is used in this work to survey environmental impacts in the production of energy from a small HPP in the Brazilian Amazon. The plant analyzed is the Curuá-Una HPP (Santarém, Pará State, Northern Brazil). These data are analyzed in the openLCA 1.4.2 software (www.openlca.org), and the Ecoinvent 3.1 dataset (www.ecoinvent.org); producing values linked to a functional unit, allowing the comparison between other plants. Hydroelectric LCA should be performed including all the phases. The results 
obtained in the present study point out the main contributors for environmental impacts of the Curuá-Una HPP and that the constructions phase is mainly responsible for the burdens. Some studies show only the operation phase, because, generally, it is very difficult to find data regarding the construction of the plants. The inventory of Curuá-Una HPP was conducted through interviews with experts who participated in the construction work, as well as technical reports.

The methodology used in this study follows the ISO standards but there are also other references for this work. LCA studies conducted by other researchers such as Turconi et al. [26] that developed a framework for environmental analysis and modeled scenarios for low carbon emission. Ribeiro [24] developed a work to create Brazilian bases of LCA using the Itaipu HPP data and Pang et al. [23] developed LCA of the small HPP in China.

The main contributions of the present work are:

- Curuá-Una HPP inventory including equipment data and infrastructure material;

- LCA of the Curuá-Una HPP covering the construction, operation and decommissioning phases;

- Evaluation of the main impact categories for these phases including Global Warming (GWP), Abiotic Depletion (ADP), Acidification (AP), Freshwater Aquatic Ecotoxicity (FAETP), Human Toxicity (HTP);

- Reports of the inputs that are major contributors of environmental impact;

- Sensitivity analysis of a different scenario, with a lower level reservoir.

The remainder of this article is organized as follows. First, the energy production scenario considering renewable energy resources in Brazil is presented; then the materials and methods are described. In the last section, results are discussed and conclusions are presented.

\section{ENERGY PRODUCTION SCENARIO CONSIDERING RENEWABLE ENERGY RESOURCES IN BRAZIL}

According to REN21 [27], 77.9\% of the electricity produced in the world is by non-renewable resources (fossil fuels and nuclear) and only $22.1 \%$ is from renewable sources. Countries with greater capacity to produce energy from renewable sources are China, USA, Brazil, Canada and Germany [28]. The Brazilian energy grid is considered an example for the world in the use of clean and renewable sources. According to the statistics the installed capacity of electric power matrix of Brazil reached in 2015, $133,914 \mathrm{MW}$, with $65.2 \%$ of hydropower, $13.8 \%$ of natural gas, $7.3 \%$ of biomass, $6.9 \%$ of oil products, complemented by other sources. With size and characteristics indicating that it is unique worldwide, Brazilian production and transmission electricity system has strong predominance of HPP's [4].

The HPP expansion takes advantage of the existing potential in the country, especially in the northern region, in the Legal Amazon. The International Amazon refers to the northern part of South America, and the Brazilian part is called Legal Amazon, covering an area of approximately $5,215,423 \mathrm{~km}^{2}$. It represents $59 \%$ of the Brazilian territory, with a population of approximately 24 million people [29]. The main energy resource of the region is through hydropower. Tucuruí $(8,370 \mathrm{MW})$ provides most of the electricity to the region, which complements the other plants like Samuel (210 MW), Coracy Nunes (78 MW), Balbina (250 MW) and Curuá-Una (30.3 MW). Thermoelectric power is used in some situations to complement the demand. The plants of Belo Monte (4,500 MW), São Luiz do Tapajós (6,133 MW), Santa Isabel (1,080 MW), Jamanxim (802 MW) among others, are expected to come on stream in the coming years and will also integrate the National Integrated System (SIN) [30]. 
The Curuá-Una HPP is located at the region of Santarém municipality. Santarém is a city in northern Brazil, in the western region of Pará state, to $2^{\circ} 47^{\prime} 22^{\prime \prime}$ south latitude and $54^{\circ} 17^{\prime} 30^{\prime \prime}$ west longitude, it is at a distance of $807 \mathrm{~km}$, straight from the city of Belém, Pará State capital. Located on the right bank of the Tapajós River, at the confluence with the Amazon River, Santarém has a tropical climate, hot and wet. It's average annual temperature varies between $25^{\circ}$ and $28^{\circ} \mathrm{C}$ with a relative humidity of $86 \%$. During the year the average rainfall is of about 1,920 millimetres. The power supply to Santarém city occurs by SIN interconnection extension at $138 \mathrm{kV}$, from the Tucuruí HPP, with a capacity of about $80 \mathrm{MW}$ for this interconnection. Curuá-Una HPP (30.3 MW) and Santarém Thermoelectric (10 MW) complement the current demand of $110 \mathrm{MW}$.

Although the HPP's represent the largest potential for energy generation, in Brazil, there are many restrictions to their deployment. Among these concerns are: large area of flooded forests and consequently the elimination of flora and fauna [28], change in the navigability of rivers [31], destruction of potential agricultural areas in order to form the reservoir [5], carbon dioxide and methane emissions [5], etc. In addition, the energy generated will not reach many remote locations (riverine and indigenous communities) because the plants will be linked directly to the SIN. The challenge is to find ways to harness this potential without causing environmental impacts, and to invest in studies for the use of other energy sources such as solar and wind.

\section{MATERIALS AND METHODS}

\section{Characterization of the Curuá-Una HPP}

The Curuá-Una HPP is located $70 \mathrm{~km} \mathrm{SW}$ from Santarém ( $2^{\circ} 50^{\prime} \mathrm{S}, 54^{\circ} 18^{\prime} \mathrm{W}$ ) in the Curuá-Una River in Brazil's Amazonian state of Pará, and it is in operation since 1977. Most of the reservoir is in the Curuá-Una River valley (57.4\%), but parts of it occupy tributary valleys of the Rivers Moju (11.7\%), Mojuí (4.4\%) and Poraquê (3.2\%), plus several small streams (2.9\%) [5]. The construction of the plant was a challenge as a work of engineering. It was the first work of it's kind in Brazil, in sandy terrain, requiring different technology from other works of this type [32], the reservoir was filled from January to May 1977, and occupies $102 \mathrm{~km}^{2}$ at its normal operating level of $68 \mathrm{~m}$ above mean sea level (see Table 1).

Table 1. Curuá-Una HPP technical parameters

\begin{tabular}{cc}
\hline Component & Description/value \\
\hline Reservoir area at normal operating level & $102 \mathrm{~km}^{2}$ \\
Reservoir volume & $472 \times 10^{6} \mathrm{~m}^{3}$ \\
Average depth of reservoir & $6 \mathrm{~m}$ \\
Drainage area & $13,600 \mathrm{~km}^{2}$ \\
Turbine & Kaplan \\
Number of turbines & 3 in operation and 1 being deployed \\
Nominal power of each turbine & $3 \times 10.1 \mathrm{MW}$ \\
Maximum output & $92.89 \%$ in the fall of $21.7 \mathrm{~m}$ \\
Transmission extension & $68.8 \mathrm{~km}$ \\
Voltage & $138 \mathrm{kV}$ \\
\hline
\end{tabular}

Source: Eletrobrás Eletronorte [33]

Initially the plant was designed to meet the demand of the cities of Santarém and Aveiro. However, with population growth greater than expected, it was necessary to add 
the extra demand through Tucuruí system, installed on the Tocantins River. Until 1985, Curuá-Una had two turbines with generating capacity of $20 \mathrm{MW}$. Nowadays, Curuá-Una has three turbines with generating a total output of $30.3 \mathrm{MW}$. The fourth turbine with 12.5 MW will be deployed by 2017, and will increase Curuá-Una capacity to $42.8 \mathrm{MW}$. The calculation of production potential for 100 years considers the real capacity of the plant with $92.89 \%$ efficiency, according to the current management of the plant. Thus, the generating production is $18 \mathrm{MW}$ during 8 years, $28 \mathrm{MW}$ during 32 years and $39 \mathrm{MW}$ to 60 years, for a total of 29,976,720 MWh in 100 years. All inputs of materials and supplies were considered for production of total energy. Curuá-Una HPP has an energy density of approximately $0.29 \mathrm{MW} / \mathrm{km}^{2}$.

\section{Goal and scope definition}

The goal of the study is to survey the life cycle environmental impacts on generation in Curuá-Una HPP by using LCA. In the first stage of LCA it is important to define the functional unit and system boundary. Thus, the amount of energy in MWh is used as functional unit. All data in the study are related to this amount of energy produced and the environmental impacts are expressed with bases in $1 \mathrm{MWh}$. According to technical planning for Curuá-Una HPP, the lifetime of the plant is 100 years, for both the equipment and the dam infrastructure. The system boundary is often a subjective decision, because it depends on the scope and purpose of the study, and should be described in detail so that comparisons between studies can be made [27]. For this study, LCA includes the stages of construction (infrastructure and equipment), operation and decommissioning (Figure 1). The transport of all the material and equipment for the implementation of the plant are also included, considering that most of these were transported through great distances. Transmission and distribution for electrical network are beyond the scope of this study.

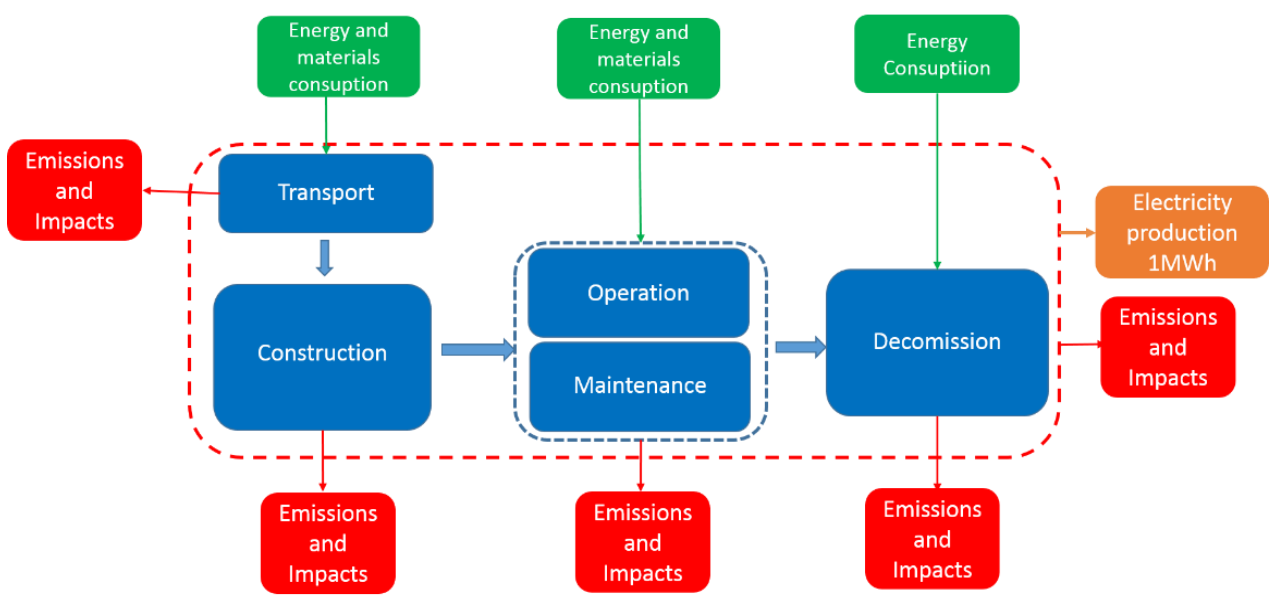

Figure 1. Boundary frontier - Curuá-Una LCA

\section{Life Cycle Inventory (LCI)}

In this phase the data collection and modelling of the system is done, and every input (raw material, fuel, water, energy, etc.) and every output (product, emissions, waste, etc.) is recorded. Data for this research include primary data, which were obtained through interviews with the technical manager of the plant and the secondary data that were obtained from literature, technical reports and from the Ecoinvent 3.1 database in the openLCA 1.4.2 platform. The inputs were quantified with regard to the functional unit of $1 \mathrm{MWh}$ and are listed in Table 2. 
Table 2. LCA inputs for the production of 1 MWh of electricity, considering $92.89 \%$ of total Curuá-Una HPP capacity

\begin{tabular}{|c|c|c|c|c|}
\hline Material & Total input & Unit & Unit input & Unit \\
\hline \multicolumn{5}{|c|}{ Construction } \\
\hline Land use - transformation to reservoir & $1.02 \mathrm{E}+02$ & {$\left[\mathrm{~km}^{2}\right]$} & $3.40 \mathrm{E}-06$ & {$\left[\mathrm{~km}^{2} / \mathrm{MWh}\right]$} \\
\hline Land use - transformation to infrastructure & $1.36 \mathrm{E}+02$ & {$\left[\mathrm{~km}^{2}\right]$} & $4.52 \mathrm{E}-06$ & {$\left[\mathrm{~km}^{2} / \mathrm{MWh}\right]$} \\
\hline Land use - occupation & $4.00 \mathrm{E}+05$ & {$\left[\mathrm{~km}^{2} \mathrm{y}\right]$} & $1.33 \mathrm{E}-02$ & {$\left[\mathrm{~km}^{2} \mathrm{y} / \mathrm{MWh}\right]^{*}$} \\
\hline Explosive & $5.10 \mathrm{E}+04$ & {$[\mathrm{~kg}]$} & $1.70 \mathrm{E}-03$ & {$[\mathrm{~kg} / \mathrm{MWh}]$} \\
\hline Timber & $4.38 \mathrm{E}+03$ & {$\left[\mathrm{~m}^{3}\right]$} & $1.46 \mathrm{E}-04$ & {$\left[\mathrm{~m}^{3} / \mathrm{MWh}\right]$} \\
\hline Diesel to generate electricity & $4.32 \mathrm{E}+06$ & {$[\mathrm{~kg}]$} & $1.44 \mathrm{E}-01$ & [kWh/MWh] \\
\hline Reinforced steel & $3.44 \mathrm{E}+07$ & {$[\mathrm{~kg}]$} & $1.15 \mathrm{E}+00$ & {$[\mathrm{~kg} / \mathrm{MWh}]$} \\
\hline Concrete & $1.46 \mathrm{E}+05$ & {$\left[\mathrm{~m}^{3}\right]$} & 4.88E-03 & {$\left[\mathrm{m}^{3} / \mathrm{MWh}\right]$} \\
\hline Asphalt project & $5.69 \mathrm{E}+06$ & {$[\mathrm{~kg}]$} & $1.90 \mathrm{E}-01$ & {$[\mathrm{~kg} / \mathrm{MWh}]$} \\
\hline Excavation & $1.78 \mathrm{E}+06$ & {$\left[\mathrm{~m}^{3}\right]$} & $5.95 \mathrm{E}-02$ & {$\left[\mathrm{~m}^{3} / \mathrm{MWh}\right]$} \\
\hline Steel to turbine/generator & $8.72 \mathrm{E}+05$ & {$[\mathrm{~kg}]$} & 2.91E-02 & [kg/MWh] \\
\hline Steel to transformator & $7.07 \mathrm{E}+04$ & {$[\mathrm{~kg}]$} & $2.36 \mathrm{E}-03$ & [kg/MWh] \\
\hline Steel to another equipments & $2.20 \mathrm{E}+05$ & {$[\mathrm{~kg}]$} & 7.34E-03 & [kg/MWh] \\
\hline Total (steel) & & & $3.88 \mathrm{E}-02$ & [kg/MWh] \\
\hline Copper to generator & $3.60 \mathrm{E}+04$ & {$[\mathrm{~kg}]$} & $1.20 \mathrm{E}-03$ & [kg/MWh] \\
\hline Copper to transformator & $1.50 \mathrm{E}+04$ & {$[\mathrm{~kg}]$} & $5.00 \mathrm{E}-04$ & [kg/MWh] \\
\hline Total (copper) & & & $1.70 \mathrm{E}-03$ & [kg/MWh] \\
\hline \multicolumn{5}{|c|}{ Transportation } \\
\hline Fluvial transport & $1.54 \mathrm{E}+07$ & {$[\mathrm{t} \mathrm{km]}$} & $5.12 \mathrm{E}-01$ & [t km/MWh] \\
\hline Aereo transport & $4.05 \mathrm{E}+06$ & {$[\mathrm{t} \mathrm{km}]$} & $1.35 \mathrm{E}-01$ & [t km/MWh] \\
\hline Lorry transport & $4.64 \mathrm{E}+07$ & {$[\mathrm{t} \mathrm{km}]$} & $1.55 \mathrm{E}+00$ & [t km/MWh] \\
\hline \multicolumn{5}{|c|}{ Operation and maintance } \\
\hline Water flow & $5.77 \mathrm{E}+11$ & {$\left[\mathrm{~m}^{3}\right]$} & $1.93 \mathrm{E}+04$ & {$\left[\mathrm{~m}^{3} / \mathrm{MWh}\right]$} \\
\hline Electricity & $1.41 \mathrm{E}+08$ & {$[\mathrm{kWh}]$} & $4.70 \mathrm{E}+00$ & [kwh/MWh] \\
\hline Transformator oil & $4.42 \mathrm{E}+05$ & {$[\mathrm{~kg}]$} & $1.47 \mathrm{E}-02$ & {$[\mathrm{~kg} / \mathrm{MWh}]$} \\
\hline GLP input & $6.24 \mathrm{E}+03$ & {$\left[\mathrm{~m}^{3}\right]$} & $2.08 \mathrm{E}-04$ & {$\left[\mathrm{~m}^{3} / \mathrm{MWh}\right]$} \\
\hline Gasoline for administrative activities & $1.73 \mathrm{E}+05$ & {$[\mathrm{~kg}]$} & $5.78 \mathrm{E}-03$ & [kg/MWh] \\
\hline Oil for administrative activities & $3.67 \mathrm{E}+03$ & {$[\mathrm{~kg}]$} & $1.22 \mathrm{E}-04$ & [kg/MWh] \\
\hline Gasoline for boats & $8.93 \mathrm{E}+04$ & {$[\mathrm{~kg}]$} & $2.98 \mathrm{E}-03$ & [kg/MWh] \\
\hline Oil for boats & $1.63 \mathrm{E}+03$ & {$[\mathrm{~kg}]$} & $5.44 \mathrm{E}-05$ & [kg/MWh] \\
\hline Diesel & $2.75 \mathrm{E}+06$ & {$[\mathrm{~kg}]$} & $9.18 \mathrm{E}-02$ & [kg/MWh] \\
\hline Total fuel support vehicles & $3.02 \mathrm{E}+06$ & {$[\mathrm{~kg}]$} & $1.01 \mathrm{E}-01$ & [kg/MWh] \\
\hline \multicolumn{5}{|c|}{ Decomissioning } \\
\hline Steel & $3.44 \mathrm{E}+07$ & {$[\mathrm{~kg}]$} & $1.15 \mathrm{E}+00$ & [kg/MWh] \\
\hline Steel (turbines) & $1.16 \mathrm{E}+06$ & {$[\mathrm{~kg}]$} & $3.88 \mathrm{E}-02$ & [kg/MWh] \\
\hline Copper & $5.10 \mathrm{E}+04$ & {$[\mathrm{~kg}]$} & $1.70 \mathrm{E}-03$ & [kg/MWh] \\
\hline Total disposal material & $3.56 \mathrm{E}+07$ & {$[\mathrm{~kg}]$} & $1.19 \mathrm{E}+00$ & [kg/MWh] \\
\hline Concrete & $3.65 \mathrm{E}+08$ & {$[\mathrm{~kg}]$} & $1.22 \mathrm{E}+01$ & [kg/MWh] \\
\hline
\end{tabular}

* $\mathrm{km}^{2} \mathrm{y}$ - corresponds to square kilometers times year, according openLCA software

Construction. Construction is the phase where there is a large consumption of materials and equipment for the infrastructure of the plant. Given the period when the plant was built, many data were calculated and weighted based on surveys conducted in other plants $[24,28]$. Cement, rock, sand, iron and steel make up the reinforced concrete used to the dam infrastructure. Although Curuá-Una is an earth-rock fill dam, it used concrete for powerhouse, adduction channel, tailrace, etc. Steel and copper to turbines, structural steel, timber, explosive, asphalt and diesel to electricity are included in the input of the construction phase. Regarding the land use, the flooded area and the infrastructure around the reservoirs is considered as transformation area. The total plant area $\left(4,000 \mathrm{~km}^{2}\right)$ was included as occupation area.

Operation and maintenance. This phase of the HPP requires fewer resources, because it uses the flow of water to generate energy. However, to keep the plant in operation some 
inputs are needed, such as lubricating oil, the fuel support vehicles, electricity, etc. Curuá-Una's last maintenance was carried out in 2011, with repairs to ensure perfect operation of the equipment. As no heavy structure was replaced, inputs concerning the maintenance phase were not included, but the increased capacity of the Curuá-Una HPP, planned for the 2017, with the further of the one turbine has been included as an operation/maintenance phase.

Transportation. The Curuá-Una plant is located at great distance from the places of production of the equipment and materials used. Thus, all the transport of equipment and materials for building the dam infrastructure were considered. It included the weight of equipment carried and the distance traveled. According to the technician responsible for the plant, some equipment such as turbines and generators were purchased from companies at São Paulo state and road transport was used to the Belém city $(2,830 \mathrm{~km})$, arriving in Santarém city by river $(876 \mathrm{~km})$. The cement came from Venezuela to Manaus by road $(2,237 \mathrm{~km})$ and by ferry to Santarém $(739 \mathrm{~km})$. Equipment such as tractors, cranes, bucket trucks, etc., came from São Paulo, using air transport. And all the material that arrived in Santarém city followed the road until the Curuá-Una plant (70 km).

Decommissioning. It is not known how the HPP ends it's lifetime, but studies presume that the dams are not removed, but abandoned or replaced. Furthermore, it seems probable that the other parts of storage power stations are replaced by new plants at the end of their lifetime [28]. Thus, it was considered that the material used in the construction would remain on-site, but being partly used for recycling.

Some inputs presented in Table 2 were calculated from information on the plant itself, and others were calculated based on other work as follows: although no direct data on consumption of explosives is available, an indirect calculation was performed. According to Ribeiro [24], it takes $0.4 \mathrm{~kg}$ of explosive for $1 \mathrm{~m}^{3}$ excavated rock. Therefore, for $127,600 \mathrm{~m}^{3}$ of rock, it takes $51,040 \mathrm{~kg}$ of explosives. The excavation volume was calculated according Itaipu data [24], considering the proportion to Curuá-Una. The timber was used only for concrete frames, considering that for each $\mathrm{m}^{3}$ of concrete, $12 \mathrm{~m}^{2}$ timber was used. The quantities of steel turbines, generators and transformers were obtained directly from the manufacturer. Since the turbine's models were those commonly used by the time of construction (more than 40 years ago), data were approximated as well as the amount of copper. The operation phase data were obtained directly from the spreadsheets provided by the management of the Curuá-Una plant. The values in Table 2 refer to the total quantities (total input column) and the ratio of the total amount of each input by the total energy produced in 100 years, in MWh (unit input column).

\section{Life Cycle Impacts Assessment (LCIA)}

The LCI results shown in Table 2 are the input to the LCIA phase and are converted into the related environmental impacts based in characterization and classification models [9]. There are different methodologies that can be applied, e.g., CML 2001, Recipe 2008, Eco-Indicator 99, IPCC 2013, TRACI and ILCD 2009 [34]. In this study, the CML 2001 method was used. The fluxes that were used to the Curuá-Una LCA were selected from the Ecoinvent database and the categories evaluated are described below.

Acidification Potential (AP). Acidification results of the sulphur dioxide $\left(\mathrm{SO}_{2}\right)$, ammonia $\left(\mathrm{NH}_{4}\right)$ or nitrogen oxides $\left(\mathrm{NO}_{\mathrm{x}}\right)$ reaction with water, causing the "acid rain". It is expressed using the reference unit, $\mathrm{kg} \mathrm{SO}_{2}$ equivalent [35]. 
Global Warming Potential (GWP - 100 years). Potential global warming expresses the climate changes referent to the global temperature caused by "greenhouse gases" released by human activity. GWP is expressed as over the time horizon of different years, being the most common 100 years (GWP100), measured in the reference unit, $\mathrm{kg} \mathrm{CO}_{2}$ equivalent [35].

Abiotic Depletion Resources (ADP). This impact category refers to the consumption of non-biological resources such as fossil fuels, minerals, metals, water, etc. The scarcity of a substance is what appoints it's depletion and is measured in antimony equivalent $[35]$.

Freshwater Aquatic Ecotoxicity Potential (FAETP). Environmental toxicity is the toxic effects of chemical on an ecosystem, in this case in the freshwater, causing biodiversity loss and/or species extinction. Characterisation factors are expressed using the reference unit, $\mathrm{kg}$ 1.4-dichlorobenzene equivalent (1.4-DCB) [35].

Human Toxicity Potential (HTP). The HTP is considered the toxic effects of chemicals on humans. It reflects the potential harm of a unit of chemical released into the environment that are caused, for the most part, by electricity production from fossil sources. HTP is measured in 1.4-dichlorobenzene equivalent, as FAETP.

\section{RESULTS AND DISCUSSION}

In this section, the main results of the present research are presented and discussed. Graphical representation and tables are used to express these results. Table 3 shows results on contribution of life cycle phases in each impact categories that are also represented in percentage in Figure 2. The complete cycle represents the total inputs of the all phases. Note that the quantities are in relation to $1 \mathrm{MWh}$ for 100 years of production. HTP, GWP and FAETP are the most affected categories, and have more emissions during the construction phase. This is because fossil fuel was used for electricity production in this phase, which is a great contributing factor in these impact categories. In the case of the Curuá-Una LCA, the transport is the most important emitter in the operating phase, since most of the equipment and materials for plant construction were brought from distant locations, various types of transport as airplanes, trucks, ferries, etc. being necessary. It is important to notice that the low results for the operation phase are due to lack of data about the emissions of $\mathrm{CH}_{4}$ and $\mathrm{CO}_{2}$ in the flooded area. These emissions should be measured directly in the reservoir. The methodology used in this work (LCA), does not include this analysis process. Negative results of the decommissioning phase is due to the waste stream and recycling used in Ecoinvent database. More investigation should be made in the case of this plant, because it is not known if there is a possibility of recycling the material, after it's disabling.

Table 3. Contribution of Curuá-Una life cycle phases in each impact category

\begin{tabular}{|c|c|c|c|c|c|c|}
\hline Impact category & Reference unit & Complete life cycle & Construction & Operation & Transp. & Decommis. \\
\hline Acidification potential - AP & {$\left[\mathrm{kg} \mathrm{SO}_{2} \mathrm{eq}\right]$} & 0.0223 & 0.0189 & 0.0009 & 0.0025 & -0.000 \\
\hline Climate change - GWP 100a & {$\left[\mathrm{kg} \mathrm{CO}_{2}\right.$ eq $]$} & 5.4659 & 4.8922 & 0.1121 & 0.4679 & -0.0065 \\
\hline $\begin{array}{c}\text { Depletion of abiotic resources - } \\
\text { ADP }\end{array}$ & [kg antimony eq] & 0.0312 & 0.0247 & 0.0033 & 0.0032 & $-0,0000$ \\
\hline $\begin{array}{c}\text { Freshwater aquatic ecotoxicity - } \\
\text { FAETP 100a }\end{array}$ & [kg 1.4-DCB eq] & 2.4505 & 2.2971 & 0.1169 & 0.0371 & -0.0007 \\
\hline Human toxicity - HTP 100a & [kg 1.4-DCB eq] & 7.2858 & 6.4277 & 0.6267 & 0.2345 & -0.0031 \\
\hline
\end{tabular}




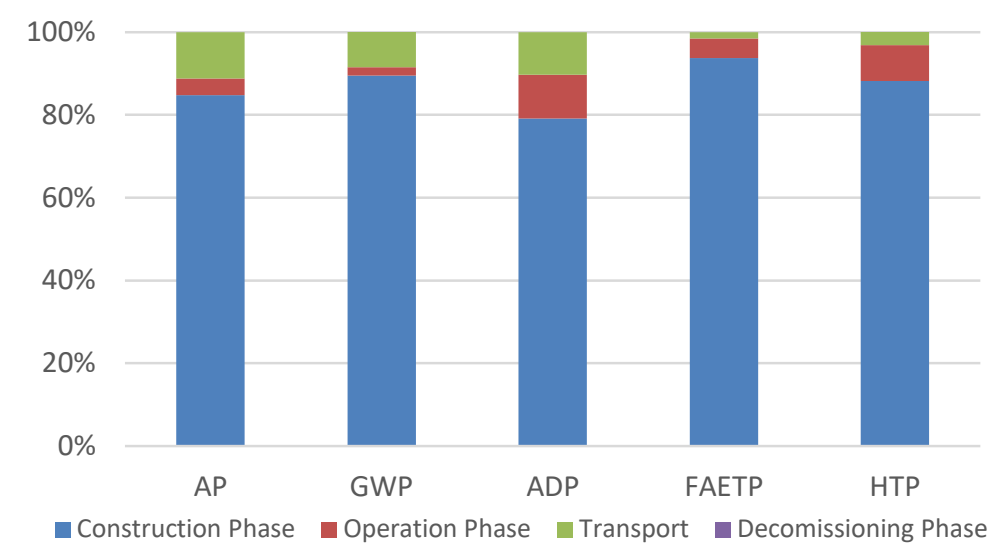

Figure 2. Percentage contribution of each phase to the impact categories

Figure 2 shows which is the most important phase in different impact categories. The construction phase contributes highly in all impact categories. The operation phase contributes with emissions to the ADP and HTP, and the transport phase with emissions to AP and ADP.

The LCA methodology also allows assessing which are the inputs that have more influence on environmental impacts. Among the inputs that are part of this work (see Table 2) the seven most significant in this graphical analysis are included, in percentage values. The results in Figure 3 show that the largest contributor to these impacts is the steel used both for infrastructure as for equipment such as turbines and generators, as shown in Table 2. The concrete used in construction phase contributed, mainly, in the amounts found to GWP, and also to AP and ADP. Transport contributed to environmental impacts AP, GWP and ADP and petroleum refinery operation to ADP.

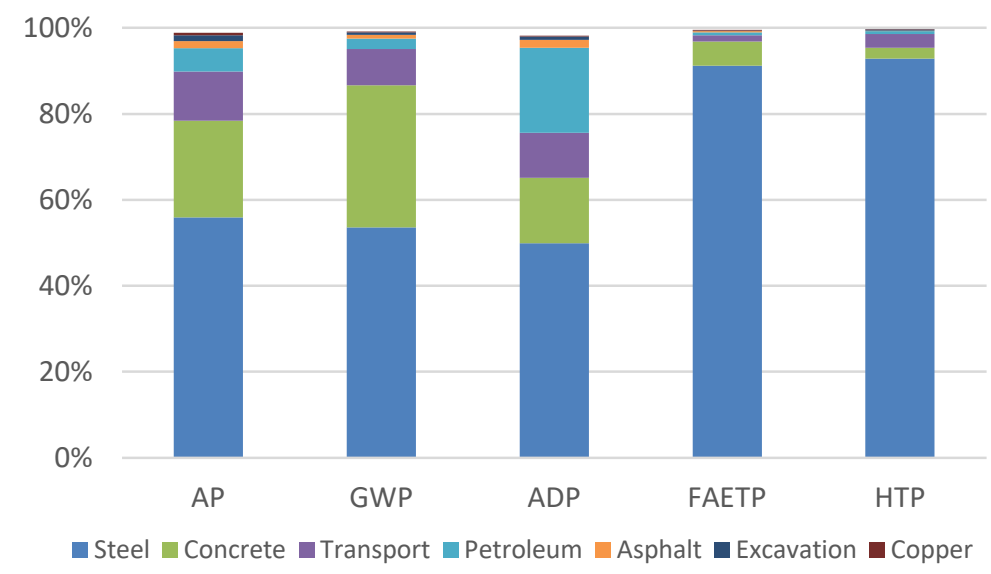

Figure 3. Percentage of inputs for impact categories

There are different methodologies to assess the environmental impacts of hydropower. A direct comparison between HPP's is difficult and should be uses with care because HPP's are highly site-specific [36] and it's environmental impacts are associated with it's characteristics. Dones et al. [17] has conducted a study based on data from more than 50 Swiss reservoir plants and highlighted that "these results should not be considered as representative for single power plants in any of these regions". Brizmohun et al. [21] conducted a study with a set of plants located in the southeast coast of the African continent. They considered the functional unit of $1 \mathrm{kWh}$ of electricity delivered to the consumer and lifetime of 150 years. The study conducted in China in hydropower 
of Guanyinyan [23] considered 30 years to HPP lifetime. Castelazo et al. [37] assessed a set of HPP's in Mexico with a total capacity of 10,566 MW. Swanit and Gheewala [38] analyzed a set of five small HPP's (run of river type), with capacity between 200 to $6,000 \mathrm{~kW}$. The results of these studies are shown in Table 4.

Table 4. Main features and results of GWP in $\mathrm{CO}_{2}$ eq/MWh of several HPP's

\begin{tabular}{|c|c|c|c|c|c|c|}
\hline References & Plant & Type & Local & Capacity [MW] & Lifetime (years) & {$\left[\mathrm{kg} \mathrm{CO}_{2} \mathrm{eq} / \mathrm{MWh}\right]$} \\
\hline & Curuá-Una & Single plant & Brazil & 30.3 & 100 & 5.46 \\
\hline [17] & $\begin{array}{l}\text { More than } \\
\text { fifty plants }\end{array}$ & $\begin{array}{l}\text { More than fifty plants } \\
\text { (average) }\end{array}$ & $\begin{array}{c}\text { Europe, non } \\
\text { alpine conditions }\end{array}$ & 9,130 & $\begin{array}{l}\text { Assumed lifetimes of } \\
\text { different parts of } \\
\text { hydropower }\end{array}$ & 10 \\
\hline [21] & Mauritius & Eight plants & Africa & 59.4 & 150 & 8.6 \\
\hline [23] & Guanyinyan & Single plant & China & 3.2 & 30 & 28.4 \\
\hline [37] & Mexico & $\begin{array}{l}\text { National electric } \\
\text { system }\end{array}$ & Mexico & 10,566 & 100 & 12 \\
\hline [38] & Thailand & Five mini HPP's & Thailand & $0.2-6$ & 50 & $11.01-23.01$ \\
\hline
\end{tabular}

The analysis suggests the need for specific studies for each plant, as it is important to consider the influence of geographical location, climate, age of the reservoir, the properties of water, etc.

\section{Sensitivity analysis}

The variation in the rain of the region promote the fluctuation in the reservoir minimizing and maximizing the water flow and have as consequence the unstable operation of the plant. In the year of the 2015, the dry season (May to September) in northern Brazil was more intense than usual, causing a reduction in the level of Curuá-Una reservoir. With the purpose of obtaining an analysis of the consequences for the environmental impacts in this condition, it was considered that the reservoir level was $4 \mathrm{~m}$ lower than its normal level, reducing its capacity to $70 \%$ (data provided by the HPP staff). The amount of energy produced with capacity of $70 \%$ for 100 years, is approximately $22,110,240 \mathrm{MWh}$. With this production factor, a simulation was performed to be compared with the normal level of production. Table 5 shows the results of the simulation of this scenario, considering the impact category expressed in Table 3.

Table 5. Scenario of low production plant and the influence in the impacts categories

\begin{tabular}{cccc}
\hline Impact category & Reference unit & $\begin{array}{c}\text { Complete life cycle } \\
29,976,720 \mathrm{MWh} \\
\text { normal level (100y) }\end{array}$ & $\begin{array}{c}\text { Complete life cycle } \\
22,110,240 \mathrm{MWh} \\
\text { low level (100y) }\end{array}$ \\
\hline Acidification potential - AP & {$\left[\mathrm{kg} \mathrm{SO}_{2}\right.$ eq $]$} & 0.0223 & 0.0321 \\
Climate change - GWP 100a & {$\left[\mathrm{kg} \mathrm{CO}_{2}\right.$ eq $]$} & 5.4659 & 7.6228 \\
Depletion of abiotic resources - ADP & {$[\mathrm{kg}$ antimony eq $]$} & 0.0312 & 0.0489 \\
Freshwater aquatic ecotoxicity - FAETP & {$[\mathrm{kg} \mathrm{1.4-DCB}$ eq $]$} & 2.4505 & 3.3790 \\
Human toxicity - HTP 100a & {$[\mathrm{kg} \mathrm{1.4-DCB}$ eq $]$} & 7.2858 & 9.9819 \\
\hline
\end{tabular}

The environmental performance in this condition was largely affected. Note that all impact categories increased when the production of the plant was reduced.

\section{CONCLUSIONS}

The aim of this study was to perform a LCA of Curuá-Una dam, advancing in research on the environmental impacts of hydroelectric dams in tropical regions. After all the efforts made in the inventory stage of this research, data were obtained from direct sources, covering many real characteristics of Curuá-Una plant, contributing to reliable results. However, some data have been obtained and adapted from other researches 
$[6,24]$, and due to lack of proper flows for this study, some inputs to the LCA used the Ecoinvent database, which built the flows based on different regions of Curuá-Una. It is important to carry out more studies on energy producing plants in the tropics, using the LCA methodologies, so that these data are consolidated, becoming a better database for these regions.

For LCA, the construction phase showed the highest contribution to environmental impacts. At this stage, the inputs that had the greatest influence were the steel used in the turbines and concrete in buildings such as spillway, penstock, powerhouse, etc. The operation phase caused no major impact when analyzed by this method. The transport of all equipment by long distances pointed to an increase in the emissions to acidification potential, global warming and depletion of abiotic resources. Hydropower has a long life, so there is no data from deactivation of a plant, however, the results must be evaluated with more supporting research on this phase.

Many studies on hydroelectric emissions have been conducted using other methodologies highlighting the plant operation phase and emissions from flooded area, overlooking the construction phase, as in $[5,36,39]$. LCA allows input of supplies in all phases, enabling a more complete study of the environmental impacts. The variation in literature and the many open questions about the origin of the environmental impacts and development over time leads to some uncertainties. However, with more studies conducted, more realistic data and information will be available.

This project is expected to provide a LCA of the Curuá-Una HPP (Santarém/Pará/Brazil), and disseminate the results so that they can be compared with other studies using this methodology. This research is part of a larger project that aims to make LCA energy production units of alternative sources and obtain solutions to support decision-making in the operation and planning of generating units that can meet the demand of the region [26]. In addition, as a result of this study an innovative methodological framework will be available for assessing environmental impacts in decision-making within the perspective of sustainable development.

\section{REFERENCES}

1. EPE, 2015, Brazilian Energy Research Company, 2015a, Technical Note DEA 03/15, Electricity Demand Forecast for the next 10 Years (in Portuguese).

2. EPE, 2015, Brazilian Energy Research Company, 2015b, 2015 Statistical Yearbook of Electricity (2014 Baseline Year).

3. IEA, 2012, International Energy Agency, Technology Roadmap, Hydropower.

4. EPE, 2015, Brazilian Energy Research Company, 2015c, Brazilian Energy Balance, 2015 (2014 Baseline Year).

5. Fearnside, P. M., Amazon's Hydroelectric Dams: Environmental and Social Impacts in Decision-making on Major Projects (in Portuguese), INPA, 2015.

6. Fearnside, P. M., Do Hydroelectric Dams Mitigate Global Warming? The Case of Brazil's Curuá-Una Dam, Mitigation and Adaptation Strategies for Global Change, Vol. 10, No. 4, pp 675-691, 2005, http://dx.doi.org/10.1007/s11027-005-7303-7

7. Fava, J. A., A Technical Framework for Life-cycle Asessments, Society of Environmental Toxicology and Chemistry and SETAC Foundation for Environmental Education, 1991.

8. Azapagic, A., Life Cycle Assessment and its Application to Process Selection, Design and Optimisation, Chemical Engineering Journal, Vol. 73, No. 1, pp 1-21, 1999, http://dx.doi.org/10.1016/S1385-8947(99)00042-X

9. ISO 14040, International Organization for Standardization, Environmental Management - Life Cycle Assessment - Principles and Framework. 
10. Foolmaun, R. K. and Ramjeawon, T., Life Cycle Assessment (LCA) of PET Bottles and Comparative LCA of Three Disposal Options in Mauritius, International Journal of Environment and Waste Management, Vol. 2, No. 1, pp 125-138, 2008.

11. Meisterling, K., Samaras, C. and Schweizer, V., Decisions to Reduce Greenhouse Gases from Agriculture and Product Transport: LCA Case Study of Organic and Conventional Wheat, Journal of Cleaner Production, Vol. 17, No. 2, pp 222-230, 2009, http://dx.doi.org/10.1016/j.jclepro.2008.04.009

12. Spielmann, M., Scholz, R. W., Tietje, O. and de Haan, P., Scenario Modelling in Prospective LCA of Transport Systems, Application of Formative Scenario Analysis, The International Journal of Life Cycle Assessment, Vol. 10, No. 5, pp 325-335, 2005, http://dx.doi.org/10.1065/lca2004.10.188

13. Yue, D., Kim, M. A. and You, F., Design of Sustainable Product Systems and Supply Chains with Life Cycle Optimization Based on Functional Unit: General Modeling Framework, Mixed-integer Nonlinear Programming Algorithms and Case Study on Hydrocarbon Biofuels, ACS Sustainable Chemistry \& Engineering, Vol. 1, No. 8, pp 1003-1014, 2013, http://dx.doi.org/10.1021/sc400080x

14. Guineé, J. B., Heijungs, R., Thuppes, A., Zamagni, A., Omassoni, P., Buonamici, R., Ekvall, T. and Rydberg, T., Life Cycle Assessment: Past, Present, and Future, Environmental Science \& Technology, Vol. 45, No. 1, pp 90-96, 2010,

15. Finkbeiner, M., Product Environmental Footprint-break Throughor Breakdown for Policy Implementation of Life Cycle Assessment? Int. J. Life Cycle Assess., Vol. 19, pp 266-271, 2014, http://dx.doi.org/10.1007/s11367-013-0678-x

16. Queiroz, A., França, L. and Ponte, M. X., The Life Cycle Assessment of Biodiesel from Palm Oil "Dendê" in the Amazon, Biomass and Energy, Vol. 36, pp 50-59, 2012, http://dx.doi.org/10.1016/j.biombioe.2011.10.007

17. Dones, R., Bauer, C., Bolliger, R., Burger, B., Heck, T., Röder, A., Emmenegger, M. F., Frischknecht, R., Jungbluth, N. and Tuchschmid, M., Life Cycle Inventories of Energy Systems: Results for Current Systems in Switzerland and other UCTE Countries, Ecoinvent Report No. 5, Paul Scherrer Institute Villigen, Swiss Centre for Life Cycle Assessment, 2007.

18. Matuszewska, D., Environomic Optimal Design of Geothermal energy Conversion System Using Life Cycle Assessment, M.Sc. Thesis, School for Renewable Energy Science, Iceland, 2011.

19. Garcia-Valverde, R., Cherni, J. A. and Urbinal, A., Life Cycle Analysis of Organic Photovoltaic Technologies, Progress in Photovoltaics: Research and Applications, Vol. 18, Issue 7, pp 535-558, 2010, http://dx.doi.org/10.1002/pip.967

20. Desideri, U., Proietti, S., Zepparelli, F., Sdringola, P. and Bini, S., Life Cycle Assessment of a Ground-mounted 1,778 kW Photovoltaic Plant and Comparison with Traditional Energy Production Systems, Applied Energy, Vol. 97, pp 930-943, 2012, http://dx.doi.org/10.1016/j.apenergy.2012.01.055

21. Laleman, R., Albretch, J. and Dewull, J., Life Cycle Analysis to Estimate the Environmental Impact of Residential Photovoltaic System in Regions with a Low Solar Irradiation, Renewable and Sustainable Energy Reviews, Vol. 15, Issue 1, pp 267-281, 2011, http://dx.doi.org/10.1016/j.rser.2010.09.025

22. Brizmohun, R., Ramjeawon, T. and Azapagic, A., Life Cycle Assessment of Electricity Generation in Mauritius, Journal of Cleaner Production, Vol. 106, pp 565-575, 2015, http://dx.doi.org/10.1016/j.jclepro.2014.11.033

23. Pang, M., Wang, C. and Zhang, L., Environmental Life Cycle Assessment of a Small Hydropower Plant in China, The International Journal of Life Cycle Assessment, Vol. 20, Issue 6, pp 796-806, 2015, http://dx.doi.org/10.1007/s11367-015-0878-7 
24. Ribeiro, F. de M., Life Cycle Assessment of Hydroelectric Generation in Itaipu-Brazil Plant: First Approach (in Portuguese), São Paulo University, São Paulo, Brazil, 2004.

25. Geller, M. and Meneses, A. A. M., Multi-Objective Optimization of Electricity Generation in Northern Brazil Based on Life Cycle Assessment, $10^{\text {th }}$ Conference on Sustainable Development of Energy, Water and Environment Systems, Dubrovnik, Croatia, 2015.

26. Turconi, R. and Astrup, T. F., Life Cycle Assessment of Electricity Systems, Technical University of Denmark, Administration, IT Service Afdelingen, Kongens Lyngby, Denmark, 2014.

27. REN21, 2014, Renewables 2014 Global Status Report, (Paris: REN21 Secretaria).

28. Flury, K. and Frischknecht, R., Life Cycle Inventories of Hydroelectric Power Generation, ESU-services Ltd, 2012.

29. IBGE, 2013, Brazilian Institute of Geography and Statistics, Special Areas, Legal Amazon, http://www.ibge.gov.br/home/geociencias/geografia/amazonialegal.shtm (in Portuguese), [Accessed: 22-August-2015]

30. ONS, National Electric System Operator, SIN's Maps, http://www.ons.org.br/ conheca_sistema/mapas_sin.aspx (in Portugese), [Accessed: 25-August-2015]

31. Sternberg, R., Damming the River: A Changing Perspective on Altering Nature, Renewable and Sustainable Energy Reviews, Vol. 10, No. 3, pp 165-197, 2006, http://dx.doi.org/10.1016/j.rser.2004.07.004

32. Ligocki, L. P., Saré, A. R. and Sayão, A. S. F. J., Safety Evaluation of Curuá-Una Dam Based on Piezometric (in Portuguese), National Seminar on Large Dams, Salvador, Brazil, 2003.

33. Northern Brazil Energy Stations S.A - Eletrobras Eletronorte, Curuá-Una HPP, www.eln.gov.br/opencms/opencms/pilares/geracao/parqueGerador/UHE/curuaUna (in Portuguese), [Accessed: 23-August-2015]

34. EC - JRC, Institute for Environment and Sustainability: International Reference Life Cycle Data System (ILCD) Handbook - General Guide for Life Cycle Assessment Provisions and Action Steps, First Edition March 2010, EUR 24378 EN, Luxembourg, Publications Office of the European Union; 2010.

35. Acero, A. P., Rodriguez, C. and Ciroth, A., LCIA Methods, Impact Assessment Methods in Life Cycle Assessment and their Impacts Categories, V 1.5.2, 2015.

36. Gagnon, L., Bélanger, C. and Uchiyama, Y., Life-cycle Assessment of Electricity Generation Options: The Status of Research in Year 2001, Energy Policy, Vol. 30, No. 14, pp 1267-1278, 2002, http://dx.doi.org/10.1016/S0301-4215(02)00088-5

37. Castelazo, E. S., Gujba, H. and Azapagic, A., Life Cycle Assessment of Electricity Generation in Mexico, Energy, Vol. 36, No. 3, pp 1488-1499, 2011, http://dx.doi.org/10.1016/j.energy.2011.01.018

38. Suwanit, W. and Gheewala, S. H., Life Cycle Assessment of Mini-hydropower Plants in Thailand, Int. J. Life Cycle Assess., Vol. 16, pp 849-858, 2011, http://dx.doi.org/10.1007/s11367-011-0311-9

39. Faria, F., Jaramillo, P., Sawakuchi, H., Richey, J. and Barros, N., Estimating Greenhouse Gas Emissions from Future Amazonian Hydroelectric Reservoirs, Environmental Research Letters, Vol. 10, No. 12, 2015, http://dx.doi.org/10.1088/1748-9326/10/12/124019 